\title{
PERAN PENYIDIK KEPOLISIAN TERHADAP ANAK YANG BERKONFLIK DENGAN HUKUM DALAM PERSPEKTIF RESTORATIVE JUSTICE
}

\author{
IMAM MUHADI \\ Pasca Sarjana Universitas Borneo Tarakan
}

\begin{abstract}
Children are the hope of the nation. But reality shows that children are still involved in various forms of crime. Meanwhile, the police as law enforcers are expected to handle criminal cases involving children as a perpetrator with a different approach, namely the approach of restroative justice. This is what becomes the rationale for research with two objectives: (1). The role of police investigators on children in conflict with the law with a restroative approach

justice; (2). Forced efforts that can be carried out by police investigators on children in conflict with the law. This research is a normative study with two approaches, namelylegislation approach and conceptual approach. Based on this approach, the overall results of the study were analyzed argumentatively qualitatively. The results of the study indicate that police investigators have a very important role

important in handling crime cases involving children by exposing the child to putting forward the approach of restroative justice. The results of subsequent research, that forced efforts by police investigators against

children who are in conflict with the law in the approach of restroative justice, which should prioritize human values by integrating the role of the community, given the development of the child's soul. The recommendation of researchers is that police investigators handling child crimes should be provided with special skills that prioritize the approachrestroative justice.
\end{abstract}




\section{Keywords: Children, Police Investigators, and Restorative Justice}

I. Pendahuluan

Indonesia adalah negara hukum yang berdasarkan Pancasila dan Undang-Undang Dasar 1945, yang memiliki komitmen untuk menjamin hak asasi manusia serta menempatkan kedudukan setiap orang sama di depan hukum dan pemerintahan tanpa ada pengecualian. Pasal 27 UUD 1945 Ayat (1), secara tegas mengatur ketentuan, sebagai berikut:

Segala warga negara bersamaan kedudukannya di dalam hukum dan pemerintahan dan wajib menjunjung hukum dan pemerintahan itu dengan tidak ada kecualinya; Ketentuan tersebut, merupakan aturan dasar konstitusional negara Indonesia guna menjamin persamaan hukum bagi semua warga negara tanpa memandang status sosial, pangkat dan jabatan, serta jenis kelamin. Persamaan hukum bagi setiap warga negara, dalam konteks kecakapan hukum tentu harus didudukkan secara proporsional, terutama bila persoalan penegakan hukum dikaitkan dengan usia dewasa seseorang yang menjadi warga negara Indonesia. Usia dewasa dalam sistem hukum Indonesia, terbagi atas dua kelompok yaitu kelompok usia anak-anak yang belum memasuki usia dewasa dan kelompok usia dewasa yang sudah tidak bisa disebut lagi sebagai kelompok anak-anak.

Kehadiran Undang-Undang Nomor 11 Tahun 2012 tentang Sistem Peradilan Anak, menjadi tonggak baru bagi penegakan hukum pidana di Indonesia terhadap perkara pidana yang merebak dalam realitas kehidupan masyarakat Indonesia, yang didalamnya terkait dengan anak, yang baik anak tersebut menjadi korban konflik hukum ataupun sebagai pelaku konflik hukum. Harapan pembuat undang-undang terhadap lahirnya Undang-Undang Nomor 11 Tahun 2012, yakni hendak menempatkan kedudukan anak sebagai seorang manusia yang harus dijaga harkat serta martabatnya, sebab anak merupakan asset bagi masa 
depan bangsa Indonesia, sehingga perlu mendapatkan perlindungan khusus, terutama perlindungan hukum dalam sistem peradilan pidana di Indonesia.

Sehubungan dengan itu, realitas perkara pidana di Indonesia sejak era millenium yang ditandai dengan pesatnya kemajuan informasi dan teknologi, telah melibatkan anak-anak baik sebagai pelaku konflik Hukum maupun yang telah menjadi korban konflik hukum. Fenomena anak yang berkonflik dengan hukum, telah menjadi tema penting yang menarik untuk dikaji secara cermat. Apalagi menurut, laporan Komisi Perlindungan Anak Indonesia (KPAI) ${ }^{32}$, sejak tahun 2014 sampai dengan 2015, anak yang berkonflik dengan hukum telah meningkat menjadi 103 kasus. Pada tahun 2017, menurut Aris Merdeka Sirait, Ketua Komisi Nasional Perlindungan Anak, sebagaimana yang dilangsir oleh koran on line Valid.News.Com, telah sampai pada level yang sangat memprihatinkan, sebagai berikut:

Pembunuhan anggota TNI, Prada Yanuar Setiawan (20) di Denpasar, Bali menambah daftar panjang kasus Anak yang Berhadapan Dengan Hukum (ABDH). Dalam kasus ini Polresta Denpasar telah menetapkan seorang anak berusia 16 tahun berinisial DKDA menjadi tersangka pelaku utama penusukan terhadap Prada Yanuar. Sebelum kasus tersebut, seorang anak berinisial AW (15) pun diketahui melakukan tindak konflik hukum yang terbilang sadis, yakni menggorok dua orang anak berusia tujuh dan sembilan tahun di Tasikmalaya, Jawa Barat, pada 30 Juni 2017. "Dua kasus ini menambah deretan panjang kasus konflik hukum yang dilakukan anak. Ini harus menjadi perhatian serius kita bersama," ucap Ketua Komisi Nasional Perlindungan Anak (Komnas PA) Arist Merdeka Sirait kepada Validnews, Selasa 11 Juli 2017. Ia memperkirakan kasus

\footnotetext{
${ }^{32}$ Education News Monitoring Service, "Tren Anak yang berkonflik dengan hukum Naik", 31 Desember 2015, https://acdpindonesia.wordpress.com/2015/12/31/tren-anak-sebagai-pelakukejahatan- naik/, diakses tanggal 4 Maret 2018
} 
ABDH di Indonesia pada tahun 2017 ini sangat mungkin meningkat jika dibandingkan dengan dua tahun belakangan. Berdasarkan data yang pengaduan yang diterima Komnas PA, di tahun 2015 lembaga tersebut menerima 730 pengaduan Anak Berhadapan Dengan Hukum (ABDH).

Data tersebut merupakan fenomena dari potret buruk anak Indonesia yang terjebak pada pusaran kriminalitas, yang tentu saja sangat menarik untuk ditelaah terutama apabila dikaitkan dengan peran aparat kepolisian sebagai penyidik dalam kasus konflik hukum yang melibatkan anak sebagai pelakunya, sehigga atas dasar pemikiran itulah, penelitian ini secara keseluruhan, hendak mengangkat isu penelitian kepada segi-segi proses penyidikan terhadap anak yang berkonflik dengan hukum dengan mengkaitkan konsep Restorative Justice sebagai dasar fundamentalnya. Isu penelitian ini, sangat penting untuk diangkat sekaligus dikaji secara cermat, mengingat penegakan hukum pidana terhadap anak di Indonesia, tidak lagi menempatkan sanksi pidana bagi anak sebagai ultimum remedium tetapi sanksi pidana bagi anak merupakan bagian integral dari upaya pembinaan serta pembimbingan bagi anak, sebagai sosok yang masih mencari jati diri.

Dalam kaitan konsep Restorative Justice yang menjadi titik singgung penelitian ini, maka peran penyidik kepolisian menjadi begitu penting untuk ditelaah terutama ketika mencermati keberadaan kepolisan negara sebagai pengayom masyarakat, sehingga dari titik pijak pemikiran inilah, penelitian juga menitikberatkan kepada pokok permasalahan utama sebagai salah satu dari isu penting penelitian, yakni peran aparat penegak hukum yang dalam hal ini pihak kepolisian sebagai penyidik dalam pemeriksaan perkara pidana yang melibatkan anak sebagai pelakunya. 


\section{Rumusan Masalah}

Bertitik tolak dari paparan latar belakang masalah penelitian, maka peneliti, menetapkan 2 pokok rumusan masalah sebagai berikut:

a. Peran Polisi terhadap anak yang berkonflik dengan Hukum dalam Persfektif Restorative Justice.

b. Upaya paksa apa saja yang dapat dilakukan penyidik kepolisian terhadap anak yang berkonflik dengan hukum dalam kaitannya dengan konsep Restorative Justice.

\section{Tujuan Penelitian}

Berdasarkan pokok-pokok rumusan masalah penelitian, maka peneliti merinci tujuan penelitian dengan tetap mempertanggungjawabkan orisinalitas penelitian sebagai berikut:

a. Untuk menganalisis peran penyidik kepolisian dalam proses penegakan hukum terhadap anak yang berhadapan dengan hukum yang ditempatkan sebagai salah satu pelakunya yang berbasis kepada konsep Restorative Justice.

b. Untuk menganalisis upaya paksa apa saja yang dapat dilakukan penyidik kepolisian terhadap anak yang berkonflik dengan hukum dalam kaitannya dengan konsep Restorative Justice.

\section{Metode Penelitian}

I. Tipe Penelitian

Berdasarkan isu penelitian hukum yang ditetapkan dalam penelitian ini, maka tipe penelitian ini diarahkan kepada penelitian hukum normatif (normative legal research). 
Karakteristik penelitian hukum normatif, yakni mencari kebenaran koherensi yang mana suatu kebenaran didasarkan pada kesesuaian antara yang ditelaah dengan aturan yang ditetapkan. Peter Mahmud Marzuki mengatakan penelitian hukum adalah suatu proses untuk menemukan aturan hukum, prinsip-prinsip hukum, dan doktrin-doktrin hukum guna menjawab isu hukum yang dihadapi. Hal tersebut sesuai dengan karakter preskriptif 33

Penelitian hukum normatif, tidaklah bertujuan mencari data lapangan secara empiris, sebab analisis yang hendak dibangun dalam penelitian hukum normatif adalah berdasarkan argumentasi hukum yang merujuk kepada aturan hukum tertulis serta pandangan atau doktrin-doktrin hukum lainnya yang lahir dari hasil pemikiran mendalam dari para ahli hukum.

\section{Pendekatan Masalah}

Menurut penjelasan Peter Mahmud Marzuki bahwa suatu penelitian hukum normatif menggunakan beberapa pendekatan sebagai satu kesatuan yang utuh, yaitu pendekatan perundangundangan (statute approach), pendekatan konseptual (conceptual approach), pendekatan kasus (case approach), dan pendekatan perbandingan (comperative approach). Berpijak dari pemikiran ini, maka penelitian ini sesuai batasan rumusan masalah, hanya menggunakan dua pendekatan sebagai alat analisisnya, yakni: Pendekatan perundang-undangan (statute approach) digunakan untuk mencari dan menemukan kerangka analisis hukum berkenaan dengan keberadaan penyidik kepolisian dalam melakukan, proses penyidikan terhadap anak yang berkonflik dengan hukum dengan mengkaitkan konsep Restorative Justice

\footnotetext{
${ }^{33}$ Peter Mahmud Marzuki, Penelitian Hukum, Edisi Revisi, Cetakan ke-8, Penerbit Kencana Prenada Media Group, Jakarta, 2013, h. 93. dari ilmu hukum.22
} 
menurut tinjauan Undang-Undang Nomor 11 Tahun 2012 tentang Sistem Peradilan Anak. ${ }^{34}$ Peneliti tidak hanya menggunakan UUPA, tetapi juga undang-undang lainnya yang relevan.

III. Pendekatan konseptual

(conceptual approach) merupakan pendekatan melalui pandangan-pandangan dan doktrin-doktrin yang berkembang dari para ahli hukum, terutama dari pakar hukum pidana, guna menelaah konsep Restorative Justice sebagai basis dalam kerangka proses penyidikan terhadap anak yang menjadi salah satu pelaku konflik hukum dalam tindak pidana, dengan mengkaitkan pembahasan peran penyidik kepolisian dalam proses penegakan hukum terhadap anak yang berhadapan dengan hukum.

\section{Pembahasan}

A. Tinjauan Normatif Penyidik Kepolisian Dalam Penegakan Hukum Pidana Terhadap Pelaku Tindak Pidana

a. Tinjauan Normatif Fungsi dan Tugas Kepolisian Sebagai Penyidik

Pasal 2 Undang-Undang Nomor 2 Tahun 2002 tentang Kepolisian Republik Indonesia menetapkan secara tegas fungsi kepolisian Republik Indonesia, sebagai berikut:

Fungsi Kepolisian adalah salah satu fungsi pemerintahan negara dibidang pemeliharaan keamanan dan ketertiban masyarakat, penegak hukum, perlindungan, pengayoman dan pelayanan kepada masyarakat.Selanjutnya, Pasal 4 UndangUndang Nomor 2 Tahun 2002 juga menegaskan bahwa:

\footnotetext{
${ }^{34}$ Ibid, 21
} 
Kepolisian Negara Republik Indonesia bertujuan untuk mewujudkan keamanan dalam negeri yang meliputi terpeliharanya keamanan dan ketertiban masyarakat, tertib, dan tegaknya hukum, terselenggaranya perlindungan, pengayoman, dan pengayoman, dan pelayanan kepada masyarakat, serta terbinanya ketentraman masyarakat dengan menjunjung tinggi hak asasi manusia.

Berdasarkan ketentuan tersebut, maka keberadaan lembaga kepolisian di Indonesia secara normatif, adalah melakukan tugastugas penegakan hukum, terutama bidang hukum pidana guna terciptanya keamanan serta ketertiban masyarakat, sehingga disinilah peran penting aparat yang bertugas dijajaran kepolisian untuk menjamin terciptanya ketentraman masyarakat dengan tetap menjunjung hak asasi manusia sebagai dasar berpijaknya. Penegasan demikian, diperkuat oleh Pasal 5 Ayat (1) UndangUndang Nomor 2 Tahun 2002 bahwa:

Kepolisian Negara Republik Indonesia merupakan alat negara yang berperan dalam memelihara keamanan dan ketertiban masyarakat, menegakkan hukum, serta memberikan perlindungan, pengayoman, dan pelayanan kepada masyarakat dalam rangka terpeliharanya keamanan dalam negeri.

Pencermatan terhadap fungsi kepolisian, sebagaimana diatur dalam Undang-Undang Nomor 2 Tahun 2002 tersebut, maka dalam konteks penegakan hukum pidana sebagai bagian integral dari kerangka tugas kepolisian guna menjaga ketertiban masyarakat Indonesia, aparat kepolisian dalam menjalankan tugas penegakan hukum pidana tersebut, ruang lingkup tugasnya, diperinci secara konkrit sebagaimana diatur dalam Pasal 13 Undang-Undang Nomor 2 Tahun 2002: 
1. Memelihara ketertiban dan keamanan masyarakat;

2. Menegakkan hukum; dan

3. Memberikan perlindungan, pengayoman dan pelayanan kepada masyarakat.

Selanjutnya, Pasal 14 Undang-Undang Nomor 2 Tahun 2002, memberikan penjabaran lebih terperinci dari tigas pokok kepolisian, yakni. Dalam menjalankan tugas pokoknya sebagaimana dimaksud dalam Pasalm 13, Kepolisian Negara Republik Indonesia bertugas:

1. Melaksanakan pengaturan, penjagaan, pengawalan, dan patroli terhadap kegiatan masyarakat dan pemerintah sesuai dengan kebutuhan;

2. Menyelenggarakan segala kegiatan dalam menjamin keamanan, ketertiban, kelancaran lalu lintas di jalan;

3. Membina masyarakat untuk meningkatkan partisipasi masyarakat, kesadaran hukum masyarakat serta ketaatan warga masyarakat terhadap hukum dan peraturan perundangundangan

4. Turut serta dalam pembinaan hukum nasional;

5. Memelihara ketertiban dan menjamin keamanan umum;

6. Melakukan koordinasi, pengawasan dan pembinaan teknis terhadap kepolisian, khusus penyidik pegawai negeri sipil, dan bentuk-bentuk pengamanan swakarsa;

7. Melakukan penyelidikan dan penyidikan terhadap semua tindak pidana sesuai dengan hukum acara pidana dan peraturan perundang-undangan lainnya 
8. Menyelenggarakan identifikasi kepolisian, kedokteran kepolisian, laboratorium forensik dan psikologi kepolisian umtuk kepentingan tugas kepolisian;

9. Melindungi keselamatan jiwa raga, harta benda, masyarakat dan lingkungan hidup dari gangguan ketertiban dan/atau bencana termasuk memberikan bantuan dan pertolongan dengan menjunjung tinggi hak asasi manusia;

10. Melayani kepentingan warga masyarakat untuk sementara sebelum ditangani oleh instansi dan atau pihak yang berwenang;

11. Memberikan pelayanan kepada masyarakat sesuai dengan kepentingannya dalam lingkup tugas kepolisian; serta

12. Melaksanakan tugas lain sesuai dengan peraturan perundang- undangan.

\section{b. Peran Penyidik Kepolisian terhadap Anak yang Berkonflik dengan Hukum}

Siapapun sepakat bahwa apapun bentuk konflik hukum pasti merupakan prilaku yang meresahkan masyarakat serta merupakan ancaman bagi pergaulan hidup damai bagi masyarakat. Pemerintah Indonesia, telah menetapkan berbagai regulasi dalam bentuk undang-undang termasuk Kitab Undang-Undang Hukum Pidana yang merupakan konkordansi dari Wetboek van Koophandel sebagai warisan dari produk kolonial Belanda, yang semua regulasi itu bertujuan untuk mencegah serta menindak bentuk-bentuk konflik hukum apapun jenisnya Kepolisian sebagai penyidik, tentu saja memiliki kewenangan untuk melakukan penyidikan terhadap pelaku yang disangka 
terlibat konflik hukum apapun di wilayah Republik Indonesia. Ketentuan ini, diatur dalam Pasal 16 UU Nomor 2 Tahun 2002 tentang Kepolisian, sebagai berikut:

Mengadakan tindakan lain menurut hukum yang bertanggung jawab, yaitu tindakan penyelidik dan penyidik yang dilaksankan dengan syarat sebagai berikut: Tidak bertentangan dengan suatu aturan hukum; selaras dengan kewajiban hukum yang mengharuskan tindakan tersebut dilakukan; harus patut, masuk akal, dan termasuk dalam lingkungan jabatannya; pertimbangan yang layak berdasarkan keadaan yang memaksa, dan menghormati hak azasi manusia.

Ketentuan tersebut, memberikan penegasan bahwa proses penyidikan bagi pelaku konflik hukum adalah tetap mengacu kepada Undang-Undang Nomor 8 Tahun 1981 tentang Kitab Undang-Undang Hukum Acara Pidana (KUHAP). Merujuk kepada KUHAP, penyidik dimaksud yang berwewenang, termasuk diantaranya adalah pejabat kepolisian. Bagi pihak kepolisian, tugas penyidikan yang dilakukan terhadap pelaku konflik hukum yang mulai dari tahap penangkapan, penggeledahan, penyitaan, pemeriksaan, penahanan, sampai kepada penyerahan berkas ke jaksa penuntut umum, tetap mengacu kepada ketentuan KUHAP, sebagaimana yang telah dipaparkan peneliti pada pembahasan sebelumnya.

Penegasan kewenangan pejabat kepolisian untuk bertindak sebagai penyidik terhadap anak yang menjadi pelaku konflik hukum juga diatur dalam Undang- Undang Republik Indonesia 
Nomor 11 Tahun 2012 tentang Sistem Peradilan Pidana Anak, sebagai berikut:

Pasal 1 angka (8): Penyidik adalah penyidik Anak. Undang-

Undang RepublikIndonesia Nomor 11 Tahun 2012 tentang Sistem Peradilan Pidana Anak.

Pasal 26 ayat:

1. Penyidikan terhadap perkara Anak dilakukan oleh Penyidik yang ditetapkan berdasarkan Keputusan Kepala Kepolisian Negara Republik Indonesia atau pejabat lain yang ditunjuk oleh Kepala Kepolisian Negara Republik Indonesia.

2. Pemeriksaan terhadap Anak Korban atau Anak Saksi dilakukan oleh

Penyidik sebagaimana dimaksud pada ayat (1).

Syarat untuk dapat ditetapkan sebagai Penyidik sebagaimana dimaksud pada ayat (1) meliputi:

a) telah berpengalaman sebagai penyidik;

b) mempunyai minat, perhatian, dedikasi, dan memahami masalahAnak; dan

c) telah mengikuti pelatihan teknis tentang peradilan Anak.

3. Dalam hal belum terdapat Penyidik yang memenuhi persyaratan sebagaimana dimaksud pada ayat (3), tugas penyidikan dilaksanakan oleh penyidik yang melakukan tugas penyidikan tindak pidana yang dilakukan oleh orang dewasa.

Pasal 27 ayat: 
1) Dalam melakukan penyidikan terhadap perkara Anak, Penyidik wajib meminta pertimbangan atau saran dari Pembimbing Kemasyarakatan setelah tindak pidana dilaporkan atau diadukan.

2) Dalam hal dianggap perlu, Penyidik dapat meminta pertimbangan atau saran dari ahli pendidikan, psikolog, psikiater, tokoh agama, Pekerja Sosial Profesional atau Tenaga Kesejahteraan Sosial, dan tenaga ahli lainnya.

3) Dalam hal melakukan pemeriksaan terhadap Anak Korban dan Anak Saksi, Penyidik wajib meminta laporan sosial dari Pekerja Sosial Profesional atau Tenaga Kesejahteraan Sosial setelah tindak pidana dilaporkan atau diadukan.

Terkait dengan anak yang yang dilaporkan melakukan tindak pidana, penyidik wajib merahasiakan identitas sang anak baik dari pemberitaan di media cetak maupun di media elektronik. Hal ini berkaitan dengan asas praduga tidak bersalah (percumption of innocent) dan juga untuk menghindarkan dampak proses stigmatisasi masyarakat terhadap anak. Dalam melakukan proses penyidikan, penyidik anak secara simpatik harus menciptakan suasana kekeluargaan agar pemeriksaan berjalan dengan lancar tanpa ada rasa ketakutan dari anak yang diproses sehingga anak tersebut mudah untuk mengungkapkan keterangan yang benar dan sejelasjelasnya. Selain juga penyidik dilarang menggunakan atribut kedinasan saat penyidikan berlangsung, hal ini dimaksudkan agar anak tidak merasa dipaksa dan diintimidasi sehingga diharapkan anak tidak mengalami trauma pasca proses penyidikan. 
Berdasarkan pertimbangan demikian, maka penyidik kepolisian seyogyanya membuat catatan dan mengetik setiap perkataan yang dikemukakan oleh anak pada saat penyidik melakukan wawancara kepada anak. Petugas seharusnya mencatat poin-poin penting dari hasil wawancara tersebut, karena itu, sebaiknya penyidik menggunakan alat perekam yang tersembunyi untuk membantu mengingatnya. Itulah urgensinya, petugas penyidik kepolisian dalam perkara tindak pidana anak, dipersyaratkan memerlukan pendidikan dan pelatihan khusus dalam menangani perkara pidana anak.

Hal ini karena anak dalam usia pertumbuhan dan perkembangannya, mutlak memerlukan perlakuan khusus seperti pemeliharaan, perawatan, arahan dan masih berada dibawah bimbingan orang tua atau walinya sampai usia dewasa. Begitu juga dengan anak yang berkonflik dengan hukum penanganannya secara hukum lebih diarahkan pada upaya pendidikan dan pembinaan yang sesuai dengan usia anak, bukan melakukan tujuan pembalasan atas perbuatan pidana yang dilakukan anak-anak. Ditinjau dari segi perspektif hukum tentang anak, menurut Nandang Sambas ${ }^{35}$ :

Ditinjau dari aspek yuridis pengertian anak dimata hukum positif Indonesia (ius constitutum/ius operatum) lazim diartikan sebagai orang yang belum dewasa (minderjarig/person under age), orang yang ada di bawah umur/keadaan di bawah umur (minderjarigheid/inferiority) atau kerap juga disebut sebagai anak yang dibawah pengawasan wali (minderjarig ondervoordij)

Penjelasan Nandang Sambas, dengan mencermati berbagai regulasi tentang usia anak di Indonesia, maka anak dapat

${ }^{35}$ Nandang Sambas, Peradilan Pidana Anak Di Indonesia dan Instrumen Internasional

Perlindungan Anak serta Penerapannya, Graha Ilmu, Yogyakarta, 2013, h. 1-4 
dikategorikan sebagai pihak yang belum cakap untuk dimintakan pertanggungjawaban hukum, sebab masih dalam tataran usia yang dianggap belum dewasa. Begitu juga, ditinjau dari perspektif perkembangan jiwa dan jasmani anak, masih dalam masa pertumbuhan dan pencarian jati diri. Sudarsono ${ }^{36}$ menyinggung keterkaitan perkembangan jiwa anak dengan tindak konflik hukum yang dilakukan oleh anak itu sendiri:

Tindakan konflik hukum yang dilakukan oleh anak-anak merupakan manifestasi dari kepuberan remaja tanpa ada maksud merugikan orang lain seperti yang diisyaratkan dalam suatu perbuatan konflik hukum yang tercantum dalam kitab Undang-Undang Hukum Pidana (KUHP) di mana pelaku harus menyadari akibat dari perbuatannya itu serta pelaku mampu bertanggung jawab terhadap perbuatannya tersebut. Dengan demikian, maka kurang pas apabila konflik hukum yang dilakukan oleh anak dianggap sebagai konflik hukum murni.

Perlakuan selama proses penyidikan pidana Anak harus memperhatikan prinsip-prinsip perlindungan anak dan tetap menjunjung tinggi harkat dan martabat anak tanpa mengabaikan terlaksananya keadilan, dan bukan membuat nilai kemanusiaan anak menjadi lebih rendah. Pada hakekatnya, segala bentuk penaganan terhadap anak yang melanggar hukum harus dilakukan dengan memprioritaskan kepentingan terbaik untuk si anak. Karena itu tindakan yang diambil penyidik apabila kasus diteruskan sampai ke persidangan harus adil dan di proporsional, serta tidak sematamata dilakukan atas pertimbangan hukum, tapi juga pertimbangan berbagai faktor lain seperti kondisi lingkungan sekitar, status sosial anak, dan keadaan keluarga. Anak yang melakukan konflik hukum tentu saja belum matang secara mental dan psikologis, sehingga

${ }^{36}$ Sudarsono, Kenakalan Remaja, Rineka Cipta, Jakarta, 1991, h. 10. 
perlu penanganan khusus dan berbeda dibandingkan pelaku konflik hukum dewasa. Melihat modus operandi konflik hukum anak saat ini, telah mengalami perubahan dimana anak telah dapat melakukan konflik hukum dengan modus operandi yang tersistematis dan terencana, maka perlu suatu pengkajian secara mendalam, mengenai hal tersebut, meliputi bagaimanakah modus operandi konflik hukum anak saat ini, serta apakah faktor penyebab anak melakukan konflik hukum dipandang dari sudut ilmu dan teori kriminologi.

Atas dasar itu, maka asas-asas yang mendasari prosedur penyidikan terhadap anak pelaku konflik hukum berbeda dengan orang dewasa. Modifikasi langkah-langkah strategis dalam politik hukum pidana bagi penanggulangan konflik hukum anak adalah bahwa kebutuhan akan keterpaduan (integritas) antara kebijaksanaan penanggulangan konflik hukum dengan politik sosial dan politik penegakan hukum.

Konteks kebijakan penanggulangan konflik hukum anak dari perilaku kenakalan anak, perlu dimodifikasi melalui kebijakan berbasis politik kesejahteraan anak dan politik perlindungan hakhak anak, baik anak pada umumnya maupun anak yang menjadi korban konflik hukum orang dewasa (neglected children) maupun korban anak pelaku kenakalan anak (delinquent children).

Menurut Retnowulan Sutianto ${ }^{37}$ perlindungan anak merupakan suatu bidang Pembangunan Nasional, melindungi anak adalah melindungi manusia, dan membangun manusia seutuh mungkin. Hakekat Pembangunan Nasional adalah pembangunan manusia Indonesia seutuhnya yang berbudi luhur. Mengabaikan masalah perlindungan anak berarti tidak akan memantapkan pembangunan nasional.

${ }^{37}$ Retno Wulan Sutianto dalam Romli Atmasasmita, Peradilan Anak Di Indonesia, Mandar Maju, Bandung, 1997, h. 166 
Akibat tidak adanya perlindungan anak akan menimbulkan berbagai permasalahan sosial yang dapat mengganggu penegakan hukum, ketertiban, keamanan, dan pembangunan nasional. Maka, ini berarti bahwa perlindungan anak harus diusahakan apabila kita ingin mengusahakan pembangunan nasional yang memuaskan. Paradigma penyidikan terhadap anak harus berdasarkan perspektif perlindungan anak, yang dalam perlindungan anak dikenal 4 prinsip dasar, yaitu:
a. non diskriminasi
b. kepentingan terbaik bagi anak
c. kelangsungan hidup,
d. tumbuh dan berkembang;
e. penghargaan terhadap pendapat anak.

sehingga dalam perspektif perlindungan anak, tidak ada pemidanaan terhadap anak dan tidak ada penjara bagi anak. Apapun alasannya, seperti apapun tindakan yang dilakukan oleh anak. Proses pemidanaan, apalagi pemenjaraan, hanya untuk orang dewasa.

Berdasarkan penjelasan tersebut, dengan mencermati Undang-Undang Nomor 11 Tahun 2012, dalam titik pandang normatif, peran penyidik kepolisian dapat memposisikan diri sebagai penegak hukum dengan menitikberatkan kepada perlindungan anak secara baik. Maknanya bahwa kepentingan terbaik anak harus dipandang sebagai paramount importance (memperoleh prioritas tertinggi) dalam setiap keputusan yang menyangkut anak. Tanpa prinsip ini, maka perjuangan untuk melindungi anak akan mengalami banyak batu sandungan. Prinsip the best interest of the child digunakan untuk melindungikepentingan anak yang diduga sebagai pelaku konflik hukum, dengan anggapan bahwa ketidaktahuan (ignorance) anak 
terhadap apa yang dilakukannya karena faktor usia dan perkembangannya.

Rumusan kewenangannya tersebut merupakan kewenangan yang bersumber dari asas kewajiban umum kepolisian (plichtmatigheids beginsel), yaitu suatu asas yang memberikan kewenangan kepada aparat kepolisian untuk bertindak ataupun tidak melakukan tindakan apapun berdasarkan penilaian pribadi sendiri dalam rangka kewajibannya menjaga, memelihara ketertiban dan menjaga keamanan umum. Kewenangan demikian dikenal dengan istilah diskresi kepolisian, yang keabsahannya didasarkan pada pertimbangan keperluannya untuk menjalankan tugas kewajibannya dan ini tergantung pada kemampuan subjektifnya sebagai petugas pada tahap penyidikan yang merupakan tahap yang penting diperhatikan, karena pengaruh yang

ditimbulkan bukan hanya dapat menentukan keberhasilan dalam proses peradilan selanjutnya, melainkan juga membawa pengaruh terhadap perkembangan jiwa anak.

Ketentuan yang diatur dalam Pasal 42 Undang-Undang Perlindungan Anak bahwa penyidik "wajib" memeriksa tersangka dalam "suasana kekeluargaan", maka aparat kepolisian yang dalam fungsi dan tugasnya sebagai aparatur penegak hukum dan sekaligus pelindung serta pengayom masyarakat, dituntut untuk lebih intensif dalam melakukan penanganan tindak pidana anak, sehingga penanganannya dapat menyentuh pada akar masalah.

Dalam konteks penyidikan terhadap anak yang berhadapan dengan hukum, maka peran penyidik kepolisian dituntut untuk mampu melakukan upaya pendekatan keadilan restorasi yang dapat mengubah atau memperbaiki sistem peradilan. Artinya lebih 
bersifat merestorasi atau memperbaiki, sehingga dapat mengubah pendekatan konsep keadilan yang sesuai dalam penanganan perkara-perkara pidana, terutama untuk melindungi kepentingan anak yang terjerat pada sebuah tindak pidana.

\section{B. UPAYA PAKSA PENYIDIK KEPOLISIAN TERHADAP ANAK YANG BERKONFLIK DENGAN HUKUM DALAM PERSFEKTIF RESTORATIVE JUSTICE}

Pada paparan selanjutnya, peneliti akan menjelaskan konsep Restorative Justice, yakni sebuah konsep penyelesaian perkara pidana berbasis keadilan yang mengakomodasikan kepentingan para pihak, yang berkonflik dan korban, melalui jalur di luar prosedur formal pengadilan, yang lebih menekankan kepada pemulihan kerugian yang disebabkan oleh perbuatan pidana, yang mekanisme penyelesaian perkaranya melalui cara-cara yang tepat dan paling baik dengan mempertemukan para pihak agaimana solusi penyelesaian perkaranya, sehingga dapat menciptakan masyarakat yang transformatif

Upaya paksa terhadap anak yang diduga pelaku konflik hukum oleh pihak penyidik kepolisian, dengan mengedepankan konsep Restorative Justice, sangat sesuai dengan amanat UndangUndang Nomor 11 Tahun 2012, yang menghendaki perlakuan terhadap anak yang berkonflik dengan hukum dengan perlakuan yang khusus dan manusiawi sesuai perkembangan usia anak. Melalui konsep Restorative Justice, peran serta masyarakat semakin diintensifkan untuk terlibat secara integral dengan pihak kepolisian ketika sedang dilakukan upaya paksa terhadap anak. Keterlibatan 
semua pihak, yakni masyarakat serta kompenen pihak terkait lainnya dalam prosedur upaya paksa terhadap anak yang berkonflik hukum terutama yang dilakukan oleh penyidik kepolisian, memang sudah menjadi amanat undang-undang peradilan pidana anak, sebagaimana dinyatakan dalam pasal 1 , sebagai berikut:

Keadilan Restoratif adalah penyelesaian perkara tindak pidana dengan melibatkan pelaku, korban, keluarga pelaku/korban, dan pihak lain yang terkait untuk bersamasama mencari penyelesaian yang adil dengan menekankan pemulihan kembali pada keadaan semula, dan bukan pembalasan.

Mencermati ketentuan tersebut, upaya paksa terhadap anak yang berkonflik hukum dengan berbasis konsep Restorative Justice, akan lebih menjamin keadilan dalam konteks perlindungan khusus bagi anak, sebab memungkinkan keterlibatan masyarakat serta semua pihak dalam melakukan kontrol serta pengawasan terhadap upaya paksa yang dilakukan oleh penyidik kepolisian, dengan beberapa manfaat yang dapat diambil sebagai berikut:

Keterlibatan masyarakat dapat mengurangi rasa kekhawatiran serta kecemasan pada diri anak bahwa yang bersangkutan bakal dikucilkan atau dicemooh oleh masyarakat;

2) Masyarakat dapat memantau secara langsung proses upaya paksa terhadap anak agar berjalan lebih profesional;

3) Peningkatan keterlibatan masyarakat akan menghasilkan pemahaman masyarakat yang lebih kuat dan dukungan komunitas yang kuat untuk sistem peradilan anak yang profesional; 
Keterlibatan masyarakat dalam menjamin pertanggungjawaban atas prilaku menyimpang anak, dapat membantu menegaskan apa saja norma- norma masyarakat yang harus menjadi standar nilai yang harus diikuti dalam berprilaku;

5) Keterlibatan masyarakat akan meningkatkan kesadaran tentang bahaya kejahatan serta menghasilkan kesepahaman bersama untuk menanggulangi kejahatan tersebut;

6)

Keterlibatan masyarakat menciptakan hubungan dalam komunitas yang dapat menawarkan dukungan kepada anak setelah melewati masa pembinaan;

Dukungan masyarakat sangat penting untuk pemulihan reintegrasi anak yang sedang dalam masa pembinaan;

8) Sanksi sosial masyarakat lebih memberikan daya efektif terutama bagi orang tua dan wali anak pelaku konflik hukum sehingga para orang tua/wali lebih ketat dalam pengawasan dan pendidikan anak-anaknya, sehingga tidak terjebak kepada prilaku yang menyimpang.

Hal terpenting dengan konsep Restorative Justice yang diintegrasikan kepada upaya paksa yang dilakukan penyidik kepolisian kepada anak yang berkonflik hukum, yakni upaya tersebut tidak dijalankan dengan karakteristik eksekusi yang seolah-olah menempatkan anak dalam status tersangka atau pelaku kriminal, tetapi upaya paksa yang dilakukan, baik dalam bentuk 
penangkapan maupun penahanan terhadap anak, adalah dalam batasan koridor pembinaan bagi anak itu sendiri, sehingga undangundang peradilan pidana anak menetapkan rambu-rambu upaya paksa terhadap anak, bagi penyidik kepolisian tidak dengan caracara sebagaimana yang berlaku kepada berkonflik lainnya, yakni melakukan pemborgolan, bahkan pihak penyidik kepolisian tidak diperkenankan memakai pakaian dinas kepolisian pada saat melakukan penyidikan terhadap anak, sebagaimana ketentuan Pasal 22 Undang-Undang Nomor 11 Tahun 2012, sebagai berikut:

Penyidik, Penuntut Umum, Hakim, Pembimbing Kemasyarakatan, Advokat atau pemberi bantuan hukum lainnya, dan petugas lain dalam memeriksa konflik Anak, Anak Korban, dan/atau Anak Saksi tidak memakai toga atau atribut kedinasan.

Keberhasilan konsep Restorative Justice, dalam penanganan perkara konflik yang melibatkan anak sebagai pelakunya, secara mendasar, sangat ditentukan oleh sinergitas antar lembaga termasuk masyarakat menopangi proses peradilan pidana anak tersebut, mulai dari tahap penyelidikan sampai kepada tahap pembinaan atau pembimbingan. Tidak hanya sinergitas, tetapi lebih penting lagi adalah ketika dilakukan upaya paksa maka sang anak tidak merasa dipaksa serta diintimidasi sehingga menimbulkan trauma bagi anak pasca dilakukannya penyidikan oleh aparat penyidik kepolisian.

Pelaksanaan upaya paksa terhadap anak yang berkonflik hukum dengan menggunakan konsep Restorative Justice, tidak lain adalah merupakan bentuk perlindungan hukum kepada anak, 
sebagaimana juga apa yang menjadi amanat convention on the rights of children (konvensi tentang hak-hak anak) yang disetujui oleh Majelis Perserikatan Bangsa-Bangsa pada tanggal 20 Nopember1989, lahirlah Keputusan Presiden Republik Indonesia No. 36 Tahun 1990 tentang pengesahan convention on the rights of children (konvensi tentang hak- hak anak).

Dari semua amanat kewajiban yang harus dilaksanakan oleh Pemerintah Indonesia pasca meratifikasi the Convention On The Rights Of Children 1989, antara lain adalah kewajiban memberikan perlakuan pada proses hukum secara adil kepada anak, sehingga secara spesifik, perlakuan upaya paksa penyidik kepolisian kepada anak terduga pelaku Konflik hukum juga mestinya memperhatikan prinsip-prinsip keadilan yang memperhatikan kepentingan anak.

Prinsip keadilan sebagai sesuatu yang paling fundamental bagi anak yang terduga berkonflik dengan hukum atau terduga terjerat dalam tindak pidana, ini berkaiotan erat dengan pertanggungjawaban pidana. Doktrin yang dikembangkan para ahli hukum pidana Indonesia, bahwa pertanggungjawaban pidana hanya dapat dikenakan kepada seseorang yang telah memasuki usia dewasa serta sehat akal pikiran dan jiwanya.

\section{B. Peran Anak yang berkonflik dengan Hukum}

Berdasarkan penjelasan tentang pertanggungjawaban pidana tersebut, dikaitkan dengan anak yang berkonflik hukum, maka status anak dapat dikatakan sebagai seseorang yang belum memenuhi kriteria sebagai subjek hukum yang dapat dikenai pertanggungjawaban pidana, sebab itu, bagi penyidik kepolisian ketika sedang melakukan upaya paksa terhadap anak yang berkonflik hokum, tindakan upaya paksa dilakukan tidak dalam 
kerangka sebagaimana upaya paksa yang dilakukan terhadap orang dewasa.

Dalam sebuah tindak pidana terdapat unsur perbuatan yang bertentangan melawan hukum. Salah satu contohnya adalah unsur kesalahan dalam rumusan tindak pidana perdagangan orang. Unsur kesalahan tersebut digambarkan secara implisit dalam rumusan untuk tujuan mengeksploitasi atau berakibat tereksploitasi orang yang berarti ada maksud untuk mengeksploitasi atau

berakibat tereksploitasi orang tersebut ${ }^{35}$. Batasan yang demikian memang berlaku untuk orang dewasa, tetapi apabila pelakunya adalah anak, tentu ada hal- hal yang sangat berbeda dengan orang dewasa. Apalagi dalam KUHP ditegaskan bahwa seseorang dapat dipertanggungjawabkan atas perbuatannya atas syarat kesadaran diri yang bersangkutan. Ia harus mengetahui dan menyadari bahwa perbuatannya itu terlarang menurut hukum yang berlaku, sedangkan seorang anak dengan karakteristik yang ada karena ketidakmampuannya, berbeda dengan orang dewasa yang memiliki cara berpikir normal akibat dari kehidupan rohani yang telah sempurna, pribadi yang telah mantap menampakkan rasa tanggung jawab sehingga dapat mempertanggungjawabkan atas segala tindakan yang telah dipilihnya ${ }^{36}$.

Sehubungan dengan itu, penyidikan bagi anak yang berkonflik hukum, seperti tindakan upaya paksa yang merupakan bagian integral dari penyidikan itu sendiri, seharusnya bertumpu kepada komitmen penegakan hukum pidana yang tidak sekedar memberikan penghukuman, dalam bentuk sanksi penjara, denda, atau hukuman mati. Khusus bagi anak itu sendiri, terutama yang berkonflik dengan hukum, komitmen penegakan hukum pidana, 
adalah untuk memberikan pengayoman kepada anak, dalam bentuk pembinaan dan bimbingan khusus. Penyidik Kepolisian dalam hal ini, penegakan hukum pidana bagi anak yang terduga dalam tindak pidana tertentu, adalah memainkan peran sebagai pengayom bagi masyarakat, sebagaimana yang menjadi fungsi pokok dari

35 Farhana, Aspek Hukum Perdagangan Orang, Sinar Grafika, Jakarta, 2010, h. 117.

\section{Nashrina, Perlindungan Hukum Pidana Bagi Anak Di}

Indonesia, Rajawali Press, Jakarta,

2011, h. 30 .

Kepolisian Indonesia, yang antara lain adalah fungsi pengayoman kepada masyarakat. Pada Pasal 2 Undang-Undang Nomor 2 Tahun 2002 tentang Kepolisian Republik Indonesia menetapkan secara tegas fungsi kepolisian Republik Indonesia, antara lain menjalankan fungsi pemerintahan negara sebagai pengayoman dan pelayanan kepada masyarakat.

Anak sebagai manusia yang masih kecil, sedang tumbuh dan berkembang, baik fisik mental maupun intelektualnya. Pada masa perkembangan tersebut setiap anak sedang berusaha mengenal dan mempelajari nilai-nilai yang berlaku di masyarakat serta berusaha meyakininya sebagai bagian dari dirinya. Sebagian kecil anak tak dapat memahami secara utuh aturan hidup di dalam masyarakat baik disebabkan oleh kurangnya perhatian orang tua, kurang kasih sayang, kurang kehangatan jiwa, kekerasan di dalam keluarga dan masyarakat yang membawa dampak pada terbentuknya sikap dan perilaku menyimpang anak di masyarakat. Sebagian perilaku menyimpang anak-anak tersebut bersentuhan dengan ketentuan 
hukum. Anak-anak inilah yang disebut anak yang berkonflik dengan hukum.

\section{Tinjauan Normatif Prosedur Upaya Paksa Penyidik Kepolisian}

\section{TerhadapAnak yang Berkonflik Hukum}

Upaya paksa secara terminologis merupakan daya upaya yang dilakukan oleh penyidik guna memperlancar pemeriksaan dalam rangka proses penegakan pidana. Upaya paksa dalam kerangka penyidikan merupakan bagian dari penindakan. Penindakan merupakan upaya paksa dalam kegiatan penyidikan tindak pidana, yang meliputi kegiatan untuk melakukan pemanggilan, penangkapan, penahanan, penggeledahan dan penyitaan. Artinya, upaya paksa (dwang middelen) dalam proses penegakan hukum (pidana) merupakan suatu upaya yang dilakukan oleh aparat penegak hukum (penyidik,jaksa,dan hakim) akan tetapi secara khusus Polisi selaku penyidik dan penyidik Pegawai Negeri Sipil (PPNS) untuk mengambil tindakan tertentu yang bersifat membatasi hak- hak asasi seseorang baik berupa penangkapan, penahanan, maupun penggeledahan serta menyita benda-benda dari orang lain demi untuk kepentingan penyidikan, penuntutan, dan pemeriksaan.

Kegiatan-kegiatan didalam penindakan pada dasarnya bersifat membatasi kebebasan atas hak-hak seseorang dan perannya dalam pelaksanaannya harus memperhatikan normanorma hukum dan ketentuan- ketentuan yang mengatur atas tindakan tersebut. Menurut Hartati S Sanusi ${ }^{38}$, undang-undang memberikan kewenangan kepada pejabat tertentu untuk melakukan pembatasan terhadap kebebasan dan kemerdekaan seseorang dalam berbagai bentuk kegiatan. Pembatasan kebebasan dari

38 37Hartati S Sanusi, "Penangkapan dan Penahanan sebagai Upaya Paksa dalam Pemeriksaan Perkara Pidana”, Jurnal Lex Crimen, Volume V, Nomor 4, Edisi April-Juni 2016, h. 
kemerdekaan ini ada yang bersifat sementara, adapula yang bersifat terhitung lama, bergantung pada bagaimana aturan hukum menentukan dan mengaturnya. Pembatasan kebebasan dan kemerdekaan ini merupakan suatu tindakan atau upaya paksa yang harus dilakukan dalam rangka mengikuti perintah undang-undang. Kitab Undang- Undang Hukum Acara Pidana telah menentukan adanya beberapa tindakan atau upaya paksa yang dapat dilakukan sehubungan dengan terjadinya tindak pidana yang dilakukan oleh seseorang. Berbagai upaya paksa tersebut adalah tindakan penangkapan, tindakan penahanan, tindakan penggeledahan, tindakan penyitaan dan tindakan pemeriksaan surat.

Dari beberapa bentuk upaya paksa yang diatur dalam Kitab Undang- Undang Hukum Acara Pidana, penangkapan adalah suatu tindakan penyidik berupa pengekangan sementara waktu kebebasan tersangka atau terdakwa apabila terdapat cukup bukti guna kepentingan penyidikan dan penuntutan dan atau peradilan serta menurut cara yang diatur dalam Kitab Undang-Undang Hukum Acara Pidana. Dengan demikian penangkapan hanya dapat dilakukan kepada tersangka atau terdakwa apabila terdapat cukup bukti guna kepentingan penyidikan atau penuntutan dan atau peradilan yang harus dilakukan menurut cara yang diatur dalam KUHAP.

Demikian juga dengan penahanan ada alasan yang harus dipenuhi untuk dapat dilakukan penahanan terhadap seorang tersangka atau terdakwa. Menurut Pasal 1 butir 21 KUHAP, penahanan adalah penempatan tersangka atau terdakwa di tempat tertentu oleh penyidik atau penuntut umum atau hakim dengan penetapannya, dalam hal serta menurut cara yang diatur dalam KUHAP. Dengan demikian penahanan dapat dilakukan oleh penyidik untuk kepentingan penyidikan oleh jaksa untuk kepentingan 
penuntutan dan oleh hakim untuk kepentingan pemeriksaan suatu perkara pidana di siding pengadilan, yang harus dilakukan menurut cara yang diatur dalam KUHAP.

Bentuk upaya paksa lainnya yang memungkinkan aparat kepolisian melakukannya dan juga sudah lazim menjadi realitas ditengah kehidupan masyarakat adalah penggeledahan. Penggeledahan yang diatur dalam No 8

Tahun 1981 pasal 32 sampai 37 tentang Kitab Undang-Undang Hukum Acara Pidana (KUHAP) merupakan suatu hal yang patut untuk mendapatkan perhatian yang khusus karena tindakan penggeledahan yang dilakukan polisi adalah dalam rangka mencari, mengumpulkan dan menganalisa barang bukti, fakta dan informasi untuk mengetahui apa yang sebenarnya terjadi dan siapa korban, saksi dan pelakunya, polisi harus mendatangi tempat kejadian perkara (TKP) dan mengolahnya. Dalam pengolahan tempat kejadian perkara (TKP), maka langkah-langkah pengolahan TKP, terdiri dari kegiatan-kegiatan:

a) Memasuki TKP baik berupa rumah/tempat tertutup lainnya atau tempat- tempat lain dalam rangka untuk;

b) Mencari mengumpulkan dan mengambil jejak/ barang bukti yang terdapat di TKP dan sekitarnya yang kaitannya dengan tindak pidana yang terjadi dan atau menangkap tersangkanya.

Pada saat polisi memasuki Tempat Kejadian Perkara (TKP) yang berupa rumah/tempat tertutup lainnya, apabila disimak bahwa tindakan memasuki rumah untuk mencari dan menyita barang bukti serta menangkap tersangka adalah merupakan tindakan penggeledahan rumah sebagaimana diatur dalam Pasal 1 butir 17 
KUHAP, maka dalam pelaksanaan kegiatan ini harus berdasarkan ketentuan-ketentuan yang mengatur tentang penggeledahan, yang mengatur tata cara masuk rumah serta kelengkapan administrasi penyidikannya. Sedangkan apabila dilihat kepentingan pencahariannya, pengumpulan dan pengambilan jejak/ barang bukti di TKP, hal ini merupakan "tindakan penyitaan" sebagaimana diatur dalam Pasal 1 butir 16 KUHAP, maka dalam kegiatan inipun harus dilaksanakan sesuai dengan ketentuan-ketentuan undangundang yang mengatur tentang penyitaan, baik yang mengatur tata cara penyitaan maupun kelengkapan administrasi penyidikannya dalam rangka mendukung pembuktian di sidang pengadilan.

Pada hakekatnya penggeledahan merupakan salah satu kegiatan penyidikan untuk memasuki rumah, tempat tinggal dan tempat tertutup lainnya untuk melakukan tindakan pemeriksaan badan atau pakaian khusus untuk mencari benda yang diduga keras ada pada badannya atau dibawa serta untuk disita, yang didalamnya akan menyangkut hak-hak warga negara. Pelaksanaan penggeledahan wajib menjunjung tinggi hukum yang berlaku.

Penggeledahan adalah tindakan penyidik yang dibenarkan undang- undang untuk memasuki dan melakukan pemeriksaan di rumah tempat kediaman seseorang atau untuk melakukan pemeriksaan terhadap badan dan pakaian seseorang. Bahkan tidak hanya melakukan pemeriksaan tapi bisa juga sekaligus untuk melakukan penangkapan dan penyitaan. (Pasal 32). Untuk kepentingan penyidikan, penyidik dapat melakukan penggeledahan rumah atau penggeledahan pakaian atau penggeledahan badan menurut tata cara yang ditentukan dalam undang-undang. Wewenang penggeladahan semata-mata hanya diberikan kepada 
pihak penyidik, baik penyidik Polri maupun penyidik Pegawai Negeri Sipil (PNS). Penuntut umum tidak memiliki wewenang untuk menggeledah, demikian juga hakim pada semua tingkat peradilan, tidak mempunyai wewenang untuk itu. Pengeledahan benar-benar ditempatkan pada pemeriksaan penyelidikan dan penyidikan, tidak terdapat pada tingkatan pemeriksaan selanjutnya baik dalam taraf tuntutan dan pemeriksaan peradilan. Pemberian fungsi itu sesuai dan sejalan dengan tujuan dan pengertian penggeledahan, yang bertujuan untuk mencari dan mengumpulkan fakta dan bukti serta dimasukan untuk mendapatkan orang yang diduga keras sebagai tersangka pelaku tindak pidana. Akan tetapi dalam melaksanakan wewenang penggeledahan, penyidik tidak boleh berdiri sendiri, tetapi mesti mendapat pengawasan Ketua Pengadilan Negeri ${ }^{38}$.

Upaya paksa selain penggeledahan oleh penyidik kepolisian, yakni penyitaan yang ketentuannya diatur secara terpisah pada dua tempat yaitu pada bab V, bagian keempat, mulai pasal 38 sampai pasal 46,sedangkan sebagian kecil terdapat pada bab XIV, bagian kedua yang dijumpai pada pasal 128 sampai dengan 130 KUHAP. Peneliti, mengurai beberapa aspek tentang kewenangan melakukan penyitaan oleh aparat penyidik kepolisian sebagaimana yang diatur dalam KUHAP.

\section{Kesimpulan}

Berdasarkan uraian analisis peneliti yang bertumpu kepada batas rumusan masalah penelitian, maka ditetapkan beberapa pokok kesimpulan:

A. Keberadaan Penyidik Kepolisian dalam proses penegakan hukum dalam sistem peradilan anak terhadap kasus dengan anak sebagai 
salah satu pelakunya, maka aparat penegak hukum dalam hal ini pihak aparat kepolisian sebagai penyidik anak, memainkan peran penting dalam penanganan terhadap anak yang berhadapan atau berkonflik dengan hukum tersebut, yang secara normatif, menurut Undang-Undang Nomor 11 Tahun 2012, anak tidak boleh diperlakukan sebagai pelaku tindak pidana sebagai orang dewasa pada umumnya, tetapi anak diperlakukan secara khusus, sebagai seorang manusia yang perlu mendapat pembinaan dan bimbingan khusus.

B. Penyidik kepolisian dalam melakukan upaya paksa terhadap anak yang berkonflik dengan hukum maka upaya-upaya tersebut, hendaknya dikaitkan dengan konsep Restorative Justice sebagaimana amanat Undang-Undang Nomor 11 Tahun 2012. Upaya paksa berbasis Restorative Justice, yakni dengan melakukan upaya paksa yang mengedepankan nilai-nilai kemanusiaan dan keadilan sesuai denganperkembangan jiwa dan usia anak, sekaligus upaya paksa yang dilakukan itu ditempuh dengan mengintegrasikan peran serta masyarakat serta pihak-pihak lainnya yang menaruh perhatian terhadap perkembangan jiwa dan masa depan anak.

C. Keberhasilan konsep Restorative Justice, dalam penanganan perkara konflik yang melibatkan anak sebagai pelakunya, secara mendasar, sangat ditentukan oleh sinergitas antar lembaga termasuk masyarakat menopangi proses peradilan pidana anak tersebut, mulai dari tahap penyelidikan sampai kepada tahap pembinaan atau pembimbingan. Tidak hanya sinergitas, tetapi lebih penting lagi adalah ketika dilakukan upaya paksa maka sang anak tidak merasa dipaksa serta diintimidasi sehingga menimbulkan trauma bagi anak pasca dilakukannya penyidikan oleh aparat penyidik kepolisian. 
D. Keadilan Restoratif adalah penyelesaian perkara tindak pidana dengan melibatkan pelaku, korban, keluarga pelaku/korban, dan pihak lain yang terkait untuk bersama-sama mencari penyelesaian yang adil dengan menekankan pemulihan kembali pada keadaan semula, dan bukan pembalasan.

Daftar Pustaka

Undang-Undang Dasar Negara Republik Indonesia Tahun 1945, Amandemen ke-IV, Ditetapkan DiJakarta Tanggal 10 Agustus 2002;

Undang-Undang Nomor 39 Tahun 1999 Tentang Hak Asasi Manusia (Lembaran Negara RepublikIndonesia Tahun 1999 Nomor 165; Tambahan Lembaran Negara Republik Indonesia Nomor

3886).

Undang-Undang 11 Tahun 2012 Tentang Sistem Peradilan Pidana Anak, (Lembaran Negara Republik Indonesia Tahun 2012 Nomor 153; Tambahan lembaran Negara Republik Indonesia Nomor 5332).

Kitab Undang-Undang Hukum Pidana (S. $1915-732$ jis. S. 1917-497, 645, mb. 1 Januari 1918, s.d.u.t.dg. UU No. 1 / 1946)

Undang-Undang Nomor 8 Tahun 1981 tentang Kitab Hukum Acara Pidana (Lembaran Negara Republik Indonesia Tahun 1981 Nomor 76; Tambahan Lembaran Negara Republik Indonesia Nomor 3209).

Undang-Undang Nomor 23 Tahun 2002 tentang Perlindungan Anak (Lembaran Negara Republik Indonesia Tahun 2002 Nomor 109; Tambahan Lembaran Negara Republik Indonesia Nomor 4235) sebagaimana telah di ubah dengan Undang-undang Nomor 23 Tahun 2002 tentang Perlindungan Anak (Lembaran Negara Republik Indonesia Tahun 2014 Nomor 297; Tambahan Lembaran Negara Republik Indonesia Nomor 5606)

Undang-Undang Nomor 1 Tahun 1974 tentang Perkawinan (Lembaran Negara Republik

Indonesia Tahun 1974 Nomor 1; Tambahan Lembaran Negara Republik Indonesia Nomor 3019) 
Undang-Undang Nomor 2 Tahun 2002 tentang Kepolisian Republik Indonesia (Lembaran Negara

Republik Indonesia Tahun 2002 Nomor 2; Tambahan Lembaran Negara Nomor4168), Kepolisian Negara Republik Indonesia merupakan bagian dari Angkatan Bersenjata Republik Indonesia, sehingga status hukum anggota Kepolisian Negara Republik Indonesia sama dengan status hukum anggota Angkatan Bersenjata RepublikIndonesia lainnya dan tunduk pada kekuasaan peradilan militer. 